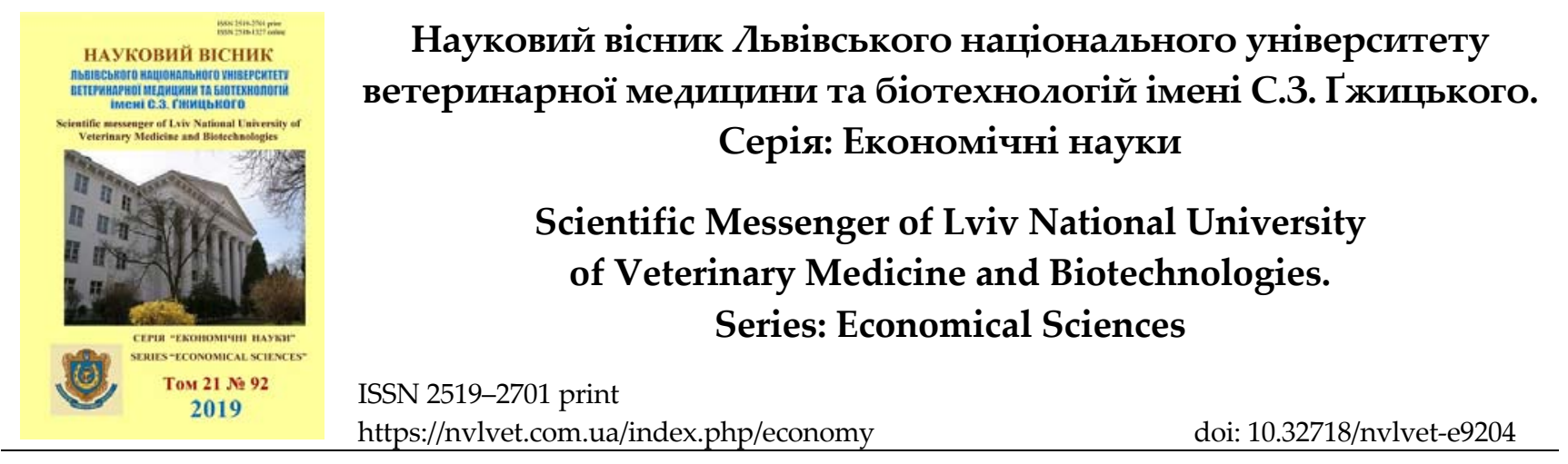

UDC 338.439 .5

\title{
Market of meat production: state, prospects of development
}

\author{
A.V. Grymak
}

Stepan Gzhytskyi National University of Veterinary Medicine and Biotechnologies Lviv, Ukraine

Article info

Received 17.01.2019

Received in revised form 21.02.2019

Accepted 22.02.2019

Stepan Gzhytskyi National University of Veterinary Medicine and Biotechnologies Lviv, Pekarska Str., 50, Lviv, 79010, Ukraine.

Tel.: +38-050-811-20-52 E-mail:Allagrimak@gmail.com
Grymak, A.V. (2019). Market of meat production: state, prospects of development. Scientific Messenger of Lviv National University of Veterinary Medicine and Biotechnologies. Series: Economical Sciences, 21(92), 21-26. doi: 10.32718/nvlvet-e9204

The discrepancy in price trends, the severe competition in the meat cattle market has affected shortened meat supplies and the supply of beef to the prices was reflected in the overall assessment of the circulation of these products in the market and statistics of the industry, in particular. Therefore, there is a situation where the supply is market in the range. The decrease in demand for meat products in connection with its increase in not balanced to demand. What causes this to happen? The analysis shows that in the development of meat cattle, a problematic situation associated with trends in socioeconomic life has occurred: low purchasing power of the population; rise in energy prices; an unequal exchange between processing enterprises and agriculture. Does not stimulate the development of the credit and tax system. This, in turn, led to a reduction in the number of animals, correspondingly a decrease in the volume of production of meat and meat products, and as a result, the level of consumption of products of the meat industry is lower than rational. As for meat cattle breeding, it should be noted that the industry has its own characteristics, not only technological but also economic ones. And if you look at the trends in the industry, the presence of its products in the market, then it would be justified and payback to work out a program of long-term development and market approval of meat cattle breeding products. What sequence of actions should help to solve perspective directions of development of the industry and its presence on the market of products? Where to start? An analysis of industry development suggests that such priority actions should be considered:

- substantiation of the number of livestock;

- analysis of animal productivity at different levels of feeding and production of beef;

- the correspondence of beef production to the processing capacity of raw materials;

- formation of volumes of market proposals for manufactured products;

- substantiation of the breakeven rate of meat cattle, taking into account the costs of production;

- according to market research data - the formation of demand in the meat products market;

- development of competitive principles, analysis of the participation of competitors in the market, studying the demand for products of the enterprise.

It should be noted that during the years of Ukraine's independence, a number of important steps have been taken to reform the agro-industrial complex, however, in this important work, the formation of a modern market environment for meat cattle-breeding, in particular the formation of a complete market infrastructure, has not yet been completed in this important work. An important task is to improve the system of relations between the services of the marketing line - from the commodity producer to the consumer of products. Of course, the implementation of state incentives for beef production, as well as opportunities for increasing the purchasing power of the population, remains topical. Detected inconsistencies in the activities of meat market operators need to deepen research aimed at eliminating them, which will improve the actual state and improve the functioning of the market products industry.

Key words: meat cattle breeding, market, stock of cattle, producers, state support.

\section{Ринок продукції м'ясного скотарства: стан, перспективи розвитку}

\author{
А.В. Гримак
}

Львівський національний університет ветеринарної медицини та біотехнологій ім. С.З. Гжицького, 


\section{м. Львів, Україна}

Невідповідність цүінових тенденцій, жорстка конкуренція на ринку продукції м'ясного скотарства позначилася на скорочені м'ясних ресурсів і поставки яловичини на ринок в асортименті. Зниження попиту на продукцію м'ясного скотарства у зв'язку із ї̈ здорожчанням знайшло своє відображення і в загальній оцінці обігу цієї продукції на ринку і статистиці розвитку галузі, зокрема. Тому склалася ситуація, коли пропозиція є не врівноваженою до попиту. Які причини спонукають до иього? Аналіз свідчить, цо у розвитку м'ясного скотарства склалась проблемна ситуація, пов'язана із тенденціями в сочіально-економічному житті: низька купівельна спроможність населення; подорожчання енергоносіїв; нееквівалентний обмін між переробними підприємствами $i$ сільським господарством. Не стимулює розвиток галузі кредитна і податкова системи. Це, в свою чергу, спричинило до скорочення поголів'я тварин, відповідно зменшення обсягів виробництва м'яса і м'ясних продуктів $і$, як наслідок, рівень споживання продукиї галузі м'ясного скотарства є нижчим рачіонального. Стосовно м'ясного скотарства, то слід зауважити, шео галузь має свої особливості, не тільки технологічні, а й економічні. І якщуо досліджувати тендениії розвитку иієї галузі, присутності ї̈ продукиії на ринку, то було б оправданим і окупним опрацювати програму перспективного розвитку і ринкового утвердження продукиії м'ясного скотарства. Яка ж послідовність дій мала б сприяти вирішенню перспективних напрямків розвитку галузі і ї̈ присутності на ринку продукиї? 3 чого почати? Аналіз розвитку галузі свідчить, що до таких периочергових дій доцільно віднести:

- обтрунтування чисельності поголів'я;

- аналіз продуктивності тварин за різних рівнів годівлі і виробництва яловичини;

- відповідність виробництва яловичини до потужностей переробки сировини;

- формування обсягів ринкових пропозицій на вироблену продукцію;

- обтрунтування рівня беззбитковості м'ясного скотарства з урахуванням обсягів затрат виробництва;

- $\quad$ за даними маркетингових досліджень - формування обсягів попиту на ринку м'ясної продукиї;

- розвиток конкурентних засад, аналіз участі конкурентів на ринку, вивчення попиту на продукцію підприємства.

Треба відзначити, щзо за роки незалежності Украӥни здійснено ряд важливих заходів із реформування в агропромисловому комплексі, однак у цій важливій роботі ще організаційно не завершено формування сучасного ринкового середовища м ясного скотарства, зокрема формування иулісної ринкової інфраструктури. Важливим завданням залишається удосконалення системи взаємовідносин служб маркетингової лінії - від товаровиробника сировини до споживача продукції. Звичайно, при иьому актуальним залишається здійснення державного стимулювання виробництва яловичини, а також можливостей підвищення купівельної спроможності населення. Виявлені невідповідності у діяльності суб'єктів ринку м'ясного скотарства потребують поглиблення досліджень, направлених на їх усунення, шчо сприятиме поліпшенню фактичного стану та удосконаленню функиіонування ринку продукиїі галузі.

Ключові слова: м'ясне скотарство, ринок, поголів'я великої рогатої худоби, товаровиробники, державна підтримка.

\section{Ветуп}

Формування ринку продукції м’ясного скотарства має за кінцеву мету соціальну спрямованість та ефективність як для товаровиробника, так і споживача. Світова практика підтверджує, що саме ринок із відпрацьованими ринковими механізмами може виступати економічним регулятором між його учасниками, формувати попит і пропозицію загалом та на продукцію м'ясного скотарства, зокрема. Вагомим внеском у дослідження відносин на ринку продуктів харчування $\epsilon$ наукові праці П.Т. Саблука, В.Я. Месель-Веселяка, П.І. Гайдуцького, В.П. Ситника, О.М. Шпичака, М.Й. Маліка, В.Г. Андрійчука, Р.І. Тринька, Т.В. Черевка, П.С. Березівського та ін (Berezivskyi, 1998; Velychko, 1998; Mesel-Veseliak \& Mazurenko, 1999; Komarnytska, 2002; Sytnyk, 2002; Sabluk, 2004; Trynko \& Hrymak, 2009; Grymak \& Urban, 2017; Chemerus et al., 2017). Хоча, слід відзначити, що їх дослідження націлюють на врахування динамічності ситуації на ринку, зокрема продукції м'ясного скотарства, тому що відбуваються зміни у нормативно-правовому забезпеченні, виникають нові взаємозв'язки й залежності. Це стосується і позитивних зрушень, які проявляються у становленні нових форм аграрних виробничих формувань, заснованих на приватній власності на землю і засоби виробництва, розвитку приватної обмінної інфраструктури, прийнятті нормативнозаконодавчих актів, гармонізованих із практикою ЄС. Високої оцінки заслуговує визнання, що Україна $є$ державою із ринковою економікою.

В аспекті досліджуваної проблеми на перспективу в пріоритет ставиться вивчення економічної сутності формування ринку у вигляді системи товарногрошових відносин, яка об'єднає підприємства на засадах рівноправності різних його форм, економічної та правової самостійності і конкурентної боротьби за споживача і місце на ринку, як і механізми вільного ціноутворення. Такий ринок мав би діяти на основі вимог законів вартості, рівноваги попиту і пропозиції і виконувати свою економічно-регуляторну функцію.

\section{Матеріал і методи досліджень}

Об'єктом дослідження були процеси забезпечення ефективності на підприємствах різних форм власності, які займаються виробництвом, переробкою і реалізацією продукції м'ясного скотарства та є учасниками ринку.

Методологічною основою дослідження слугували методи пізнання, порівняння, аналізу стану ринку продукції м'ясного скотарства та нормативних документів щодо розвитку цієї галузі.

Інформаційною базою дослідження слугувала фінансова і статистична звітність, наукові публікації по темі.

\section{Результати та їх обговорення}

Західний регіон України, у т.ч. і Львівська область, має сприятливі природно-кліматичні та економічні умови для ефективного функціонування і розвитку ринку продукції м'ясного скотарства. У цьому суттеву роль відіграють й історичні аспекти: населення регіону переважно орієнтувалось на розвиток індивідуальних, приватних господарств, розведення різних 
видів худоби і птиці. I не випадково в аграрному секторі цього регіону більшу питому вагу займає виробництво продукції тваринництва.

Однак, за останні десятиріччя в аграрному секторі намітились стримуючі тенденції. Серед основних причин слід виділити такі, як відсутність достатнього практичного досвіду на початкових етапах переходу до ринкової моделі розвитку, що в значній мірі призвело до розбалансування економічних зв'язків і поставило м'ясне скотарство перед необхідністю реформування. Не менш важливою проблемою для м'ясного скотарства стала віра у всесильність ринкових регуляторів, зокрема тих, які передбачали невтручання держави в економіку. Як і припинення державних закупівель, що поставило виробників продукції м'ясного скотарства, зокрема сировини, у залежність від переробних підприємств. Не менш важливою проблемою як для виробників, так і переробників м'яса є висока вартість кредитів, низькі закупівельні ціни на сировину. Однією із основних причин ситуації в галузі м'ясного скотарства та його збитковості $є$ постійний ріст затрат і собівартості продукції, запровадження вільних цін. Останні не відшкодовують затрат, внаслідок чого галузь нерентабельна. Має місце диспаритет цін на сільськогосподарську продукцію та продукцію переробних підприємств. Суттєвими факторами, які також позначаються на ефективності галузі м'ясного скотарства $є$ зростання вартості кормів, низька платоспроможність населення.
Викладені проблеми суттєво позначились на розвитку галузі м'ясного скотарства, хоча аналіз свідчить про перманентний характер негативних тенденцій у м'ясному скотарстві. Свідченням цього є скорочення поголів'я худоби взагалі, у тому числі й тварин відгодівельного стада (табл. 1). Ця тенденція не оминула і Львівської області.

\section{Таблиця 1}

Динаміка чисельності поголів'я великої рогатої худоби, тис. голів

\begin{tabular}{ccc}
\hline \multirow{2}{*}{ Роки } & \multicolumn{2}{c}{ Поголів'я великої рогатої худоби } \\
\cline { 2 - 3 } & усього & у т. ч. корови \\
\hline 2013 & 250,5 & 152,4 \\
2014 & 240,4 & 146,6 \\
2015 & 210,3 & 136,7 \\
2016 & 203,4 & 129,7 \\
2017 & 195,3 & 121,3 \\
2017 до 2013, \% & 78,0 & 79,6 \\
\hline
\end{tabular}

Джерело: підготовлено А.В. Гримак за даними Головного управління статистики Львівської області

Це, в свою чергу, позначилось і на виробництві яловичини переробними підприємствами (табл. 2).

\section{Таблиця 2}

Виробництво яловичини та телятини переробними підприємствами Львівської області, т

\begin{tabular}{ccccccc}
\hline \multirow{2}{*}{ Найменування продукції } & \multicolumn{4}{c}{ Роки } & \multicolumn{2}{c}{2017 до 2013, } \\
\cline { 2 - 6 }$\%$ & 2013 & 2014 & 2015 & 2016 & 2017 \\
\hline яловичина і телятина & 2036 & 1224 & 986 & 1072 & 818 \\
\hline
\end{tabular}

Джерело: підготовлено А.В. Гримак за даними Головного управління статистики Львівської області

Які ж заходи були б оправданими для стабілізації розвитку м'ясного скотарства і сприяли поступальному розвитку цієї галузі на перспективу? За результатами аналізу ефективною була б розробка програми послідовності наступних дій:

- обгрунтування чисельності поголів'я тварин в усіх категоріях господарств;

- збалансування кормовиробництва;

- розрахунки продуктивності тварин за різних варіантів забезпечення кормами i валового виробництва яловичини;

- відповідність розвитку м'ясного скотарства потужностям переробки сировини на готові продукти споживання;

-вивчення і формування обсягів пропозиції на ринку м'ясної продукції;

- аналіз обсягів попиту на ринку м'ясної продукції, виходячи із рівнів споживання м'яса населенням;

-пошук і співпраця із інвесторами, які були б готові направляти інвестиції у розвиток галузі;

- законодавчо-нормативне регулювання системи доступності надавання кредитів під прийнятні відсотки та системи страхування;

-передбачити конкретні заходи по усуненню небажаних ризиків в галузі м'ясного скотарства та переробки сировини.

Реалізуючи названі дії (заходи) в числі першочергових перспективних завдань, за результатами аналізу i досліджень, має бути конкретний курс на призупинення тенденцій скорочення поголів'я великої рогатої худоби на відгодівлі й дорощуванні і подальше його нарощування.

Дослідження підтверджують і необхідність відновлення якісних показників структури стада тварин, які має забезпечувати селекційно-племінна робота, в якій допущена низка недоліків. Правда, спостерігаються деякі зрушення. В Україні для виробництва високоякісної яловичини використовується м'ясна худоба імпортних і вітчизняних порід. Практика підтверджує високі продуктивні характеристики таких порід, як Герефордська, Абердин-Ангуська, Симентальська (комбінована), Українська м'ясна, Волинська, Поліська та ін., які успішно зарекомендували себе при створенні племінних ядер для розведення худоби м'ясного напрямку (Trynko \& Hrymak, 2009). За даними інституту розведення і генетики тварин НААН, у Львівсь- 
кій області районованими породами є Волинська м’ясна, яка розводиться в агропідприємстві “Добросин”, Жовківського р-ну, Поліська м'ясна у ТзОВ “Авангард” Буського р-ну, СТОВ “Верховина” Самбірського району, ТзОВ “Клен” Жовківського району. Симентали і порода Лімузин розводяться в ЗАТ “Медвежа Воля" Дрогобицького і ТзОВ "Відродження" Жидачівського районів.

Наступним дуже важливим перспективним напрямком є зміцнення кормової бази в господарствах різних форм власності. Це дозволить уже в найближчі роки значно збільшити чисельність поголів'я великої рогатої худоби та, відповідно, виробництво молока і м'яса, що сприятиме підвищенню рівня економічної ефективності виробництва продукції скотарства. Належна кормова база $з$ високою поживністю кормів і концентрацією обмінної енергії може гарантувати підвищення м'ясної продуктивності всього поголів'я великої рогатої худоби через зростання середньодобових приростів до 800-900 гр. і збільшення живої маси молодняку при реалізації до 500-800 кг у 18-20місячному віці (Trynko \& Hrymak, 2009). Це те, що забезпечує економічність розвитку галузі.

Окремо слід виділити можливості державної підтримки ринкового розвитку м'ясного скотарства. Йдеться про стимулювання вітчизняного товаровиробника та навіть дотування у вигляді доплат до цін, за якими закупляється м'ясна сировина. У цьому форматі підтримки товаровиробника окремим напрямком державної підтримки, ефективним й економічно оправданим мало б бути підвищення платоспроможного попиту населення, а це і заробітна плата, пенсії і т. ін.

Однією із основних передумов стабілізації галузі м'ясного скотарства, підвищення іiі ефективності й конкурентоспроможності є розвиток і зміцнення інтеграційних процесів. Важливо використовувати в м'ясопереробній галузі доступні можливості інтеграції із профільними переробними і торгівельними підприємствами, і в першу чергу із тими, які мають досвід роботи на ринку.

Інтеграція у м'ясопродуктовому підкомплексі має низку суттєвих переваг, а саме (Hrymak, 2004; Hrymak, 2017):

- досягнення органічного поєднання виробництва сільськогосподарської сировини та іiі переробки в єдиній організаційно-виробничій структурі;

- забезпечення цілісності технологічного ланцюга у виробництві кінцевих продуктів;

- зменшення залежності переробних підприємств від виробників сільськогосподарської сировини;

- збільшення можливостей впливати на якісні показники сировини і готової продукції м'ясного скотарства.

В дослідженнях ряду учених, зокрема О.П. Комарницької йдеться, що в умовах ринкових відносин основними товаровиробниками м'ясної продукції повинні стати крупнотоварні, висококонцентровані підприємства, сільські сільськогосподарські кооперативи, перевагами яких є змога утримувати стада тва- рин у кілька сотень, а то й тисяч голів, застосування сучасних технологій, технічних засобів, раціональних, окупних форм організації виробництва i праці (Komarnytska, 2002).

Досвід підтверджує, що діяльність підприємстввиробників м'ясопродуктового підкомплексу в ринкових умовах буде результативною, коли враховуватимуться наступні вимоги:

- у ринкових умовах діяльність підприємств повинна базуватись на поєднанні ефективного та якісного виробництва продукції, задоволенні потреб споживачів, формуванні прибутків, які скеровувались би переважно на розвиток і модернізацію виробництва відповідно до сучасних вимог;

- вивчення кон'юнктури ринку конкретної продукції $з$ тим, щоб економічно обгрунтовано організувати виробництво, врахувати при цьому вимоги ринку;

- постійно дбати про рівень кваліфікації працівників підприємств;

- вивчати та удосконалювати форми реалізації продукції, при цьому активно використовувати можливості реклами;

- розвивати маркетингову діяльність, мати якомога повнішу інформацію про ринок, за рахунок чого формувати нові моделі збуту продукції, розвивати власну фірмову торгівлю, входити в об’єднання й асоціації, що дозволить забезпечувати комплексність у виробництві продукції, нарощувати iï асортимент, запровадити стандарти якості і чітко контролювати їх дотримання;

- застосовувати виважену цінову політику по всьому ланцюгу виробництво-переробка-продаж продуктів споживачам;

- активно сприяти прискоренню процесів налагодження співпраці (інтеграції) сільських товаровиробників сировини i м'ясопереробних підприємств у рамках м'ясопродуктового підкомплексу на договірних умовах;

- заохочувати організацію на базі товарних сільськогосподарських і переробних підприємств спільних підприємств, в умовах яких у комплексі вирішуватимуться питання технічної модернізації виробництва сировини та іï переробки, інвестиційної політики та iн.;

- відпрацювати програму довгострокового, у тому числі й пільгового кредитування сільськогосподарських і переробних підприємств різних форм власності для зміцнення їх матеріальної бази та розвитку галузей, які безпосередньо впливають на ефективність і продуктивність м'ясного скотарства;

- обгрунтувати необхідність цільового державного дотування галузі м'ясного скотарства.

\section{Висновки}

На підставі проведеного дослідження й аналізу функціонування та розвитку ринку м'ясного скотарства можна зробити наступні висновки.

1. Ринок продукції м'ясного скотарства, як складова частина продовольчого ринку, являє собою сукупність соціально-економічних відносин, які виникають у процесі виробництва, переробки, збуту і споживан- 
ня яловичини та телятини. Критерієм ефективності його функціонування може бути забезпечення максимально можливих обсягів виробництва високоякісної i, за можливості, якнайдешевшої яловичини для наповнення нею ринку відповідно до попиту споживачів.

2. Оцінка стану галузі м'ясного скотарства свідчить про скорочення поголів'я великої рогатої худоби на відгодівлі у всіх категоріях господарств. Основною причиною такої негативної тенденції $€$ збитковість м'ясного скотарства. Дослідження її причин показало найвагоміший вплив чинника продуктивності тварин, а також собівартості продукції. У свою чергу, вони залежать від породного складу тварин, рівня годівлі, якості кормів, затрат праці, рівня механізації трудомістких процесів в усіх категоріях господарств.

3. Проведені дослідження свідчать, що кормова база є одним із вагомих чинників, формуючих розвиток м'ясного скотарства.

4. Доведено, що невід’ємною умовою ефективного господарювання в м'ясному скотарстві $\epsilon$ активне використання переваг ринкових відносин і результатів маркетингових досліджень. Використання в практиці м'ясного скотарства маркетингової інформації дозволяє створити реальну основу для розробки пропозицій щодо подолання економічного і технологічного відставання галузі, опрацювати стратегічний план розвитку іiі підприємств. Цьому сприятиме створення маркетингової служби у межах адміністративного району.

5. Встановлено, що виробничо-економічні зв'язки у м'ясному підкомплексі АПК виступають як результат взаємопогодженої співпраці на стадіях виробництва сировини, переробки та споживання готової м'ясної продукції. Проте, мають місце деякі суперечності у відносинах товаровиробників і переробників щодо диспаритету цін на сировину і продукти іiї переробки. Як спосіб виходу з цієї господарської ситуації пропонується створення інтегрованих систем у рамках м'ясопродуктового підкомплексу на основі договірних засад. Економічні й виробничі зв'язки між їх учасниками доцільно формувати у напрямах створення асоціацій, концернів, сільських кооперативів та інших структур. Такі інтеграційні формування виступатимуть чинником стримування цін кінцевого продажу, сприяючи підвищенню купівельної спроможності завдяки оптимізації розмірів сировинних зон переробних підприємств, транспортних потоків сировини і технологічних відходів переробки, поліпшенню використання побічної продукції, поглибленню спеціалізації й посиленню кооперації, підвищенню продуктивності праці.

6. У практиці функціонування ринкових відносин обгрунтованим $є$ зменшення прямого продажу сировини м'ясного скотарства переробним підприємствам. Недостатньо використовуються можливості біржових торгів щодо продажу продукції м'ясного скотарства на наявних біржах.

7. У найближчій перспективі значну роль у постачанні сировини продовжуватимуть відігравати господарства населення. Для активізації їх діяльності розроблено схеми дрібногуртового ринку з продажу продукції м'ясного скотарства, що сприятиме оптимізації взаємовідносин між партнерами, забезпечить економічно обгрунтовані ціни.

8. Серед рекомендованих заходів є пропозиції щодо стимулювання вітчизняного товаровиробника, у т.ч. й дотування у вигляді доплат до цін. Окремий напрям державної політики - підвищення платоспроможності попиту населення за рахунок регулювання структури доходів, що дозволило б підвищити річний сукупний споживчий попит взагалі, у т.ч. і на яловичину.

9. Узагальнено раціональні параметри розвитку ринку яловичини з урахуванням виявлених у процесі дослідження негативних чинників причин скорочення можливостей скотарства, а також позитивних тенденцій. На їх основі і за результатами проведених розрахунків встановлені раціональні параметри структури стада, де 55-60\% займає поголів'я корів, що дозволить збільшити і обсяги виробництва м'яса. Для перетворення галузі на прибуткову найприйнятнішим шляхом $є$ зростання продуктивності тварин. Лише за умови досягнення середньодобового приросту у межах 600-650 г м'ясне скотарство зможе перетворитись у рентабельну галузь. Раціональне використання наявних у регіоні ресурсів дозволить досягнути $12-$ 13\%-го рівня рентабельності виробництва продукції скотарства.

Перспективи подальших досліджень. Будуть продовжуватись дослідження ринку продукції м'ясного скотарства у Львівській області в динаміці та розробка перспективних напрямів його розвитку.

\section{References}

Berezivskyi, P.S. (1998). Otsinka ta prohnoz sytuatsii na vnutrishnomu rynku produktiv skotarstva Karpatskoho rehionu. Lviv: LDAU, 50 (in Ukrainian).

Chemerus, V., Dushka, V., \& Maksym, V. (2017). Consisting and basic tendencies of distributive policy of pork production enterprises in Lviv area. Scientific Messenger LNUVMBT named after S.Z. Gzhytskyj, 19(76), 112- 117. doi: 10.15421/nvlvet7622.

Grymak, A., \& Urban, I. (2017). Economic methods of market research of meat industry, their essence and objectivity. Scientific Messenger LNUVMB, 19(81), 98-101. doi: 10.15421/nvlvet8117.

Hrymak, A.V. (2004). Problemy nalahodzhennia intehratsiinykh vidnosyn mizh uchasnykamy rynku miasa (markety-nhovyi aspekt). Zb. nauk. pr. Formuvannia rynkovoi ekonomiky. Spets. vyp.: Suchasni problemy teorii i praktyky marketynhu. K.: KNEU, 321-330 (in Ukrainian).

Hrymak, A.V. (2017). Assessment of economic development and trends beef cattle lviv region. Scientific Messenger LNUVMBT named after S.Z. Gzhytskyj, 19(76), 43-46. doi: 10.15421/nvlvet7609.

Komarnytska, O.P. (2002). Formuvannia rynku velykoi rohatoi khudoby. Ekonomika APK, 12, 103-105 (in Ukrainian).

Mesel-Veseliak, V.Ia., \& Mazurenko, O.V. (1999). Ekonomichni vidnosyny uchasnykiv intehrovanoho formuvannia. K.: UAAN IAE (in Ukrainian). 
Sabluk, P.T. (2004). Rozvytok miasoproduktovoho pidkompleksu Ukrainy. K.: NNTs IAE (in Ukrainian).

Sytnyk, V.P. (2002). Transformatsiia APK Ukrainy v rynkovi umovy. K.: IAE UAAN (in Ukrainian).

Trynko, R.I., \& Hrymak, A.V. (2009). Rynok produktsii miasnoho skotarstva: stan, perspektyvy rozvytku. Monohrafiia. Lviv. TzOV "Liha Pres" (in Ukrainian).
Velychko, A.V. (1998). Marketynh yak skladova ekonomichnykh rishen $\mathrm{v}$ rehuliuvanni rynku miasnykh resursiv. Zb. nauk. pr. Aktualni problemy medytsyny, biolohii, veterynarii i silskoho hospodarstva. Lviv, 293-294 (in Ukrainian). 